\title{
ИСПИТИВАЊЕ ЧИТАЛАЧКИХ КОМПЕТЕНЦИЈА УЧЕНИКА НА СРЕДЊОВЕКОВНИМ ТЕКСТОВИМА
}

\begin{abstract}
АПСТРАКТ: Читање са разумевањем је комплексна вештина од које зависи разумевање градива сваког предмета. Стога постаје пракса да се не тестира шта ученици могу да запамте и репродукују, већ у којој мери су способни да примене своје читалачке вештине. За потребе овог истраживања спроведено је тестирање вештине читања у Првој београдској гимназији. Исти тест радили су ученици свих разреда, те је праћен развој компетенција на различитим узрастима. Тестирање је извршено пре него што су ученици првог разреда упознати са поетиком средњовековне књижевности. Стога је било погодно анализирати како познавање поетике стилске формације утиче на разумевање текстова који јој припадају. Очекивано је да ученици првог разреда остваре лошије резултате, јер се сусрећу са недовољно познатим семантичким и граматичким структурама. Анализом резултата указано је на занимљиве и неочекиване условљености између узраста, познавања поетичких одлика епохе и постигнућа на тесту. Раду је прикључен тест, спецификација са образовним стандардима и нивоима постигнућа, графички приказ постигнућа према узрасту, као и ученичка евалуација теста.
\end{abstract}

Кључне речи: читалачке компетенције, вештина читања, средњовековна књижевност.

\section{EXAMINATION OF STUDENTS' READING COMPETENCES ON MEDIEVAL TEXTS}

\begin{abstract}
Reading comprehension is a cross-curricular skill on which the understanding of the each subject depends. Therefore, it has become a practice not to test what students can remember and reproduce, but to what extent they are able to apply their reading skills. For the purpose of this research the testing of reading skills was conducted in the First Belgrade Gymnasium. The same test was done by the students of all grades and the development of competences at different ages was monitored. Testing was done before the students of the first grade were introduced to the poetics of medieval literature. It was therefore convenient to analyze how the knowledge of medieval poetics influences the understanding of the texts that belong to it. In the first class students were expected to accomplish worse results because they encountered less well-known semantic and grammatical structures. The analysis of the results shows interesting and unexpected connections between the age, the knowledge of the poetic qualities and the achievements on the test. The paper is accompanied by a test, a specification with educational standards and levels of achievement, a graphical representation of achievement by age, and a student evaluation of the test.
\end{abstract}

Key words: reading competencies, reading skills, medieval literature. 


\section{1. УВОД}

Одабир ове теме вишеструко је мотивисан. Читалачке компетенције представљају важан предуслов за успешно учешће у друштву. Савремене образовне политике се све више фокусирају на стицање функционалних знања и на припремање младих људи за процес целоживотног учења. Упоредо са новинама у образовним концептима, мењају се и концепти тестирања. Стога постаје пракса да се не тестира само шта ученици могу да запамте и репродукују, него и колико су способни да примене своје вештине у ситуацијама када им није потребно предзнање. Читање са разумевањем је вештина коју би требало развијати од најранијих узраста школовања. Пре свега, то је комплексна вештина од које зависи разумевање градива било ког школског предмета. Драгоцене смернице у овој области наставницима пружају образовни стандарди. Упућивањем у образовне стандарде, наставници стичу увид у то којим вештинама ученик треба да овлада до краја одређеног циклуса школовања. У наставним програмима ова област, нажалост, није довољно заступљена. Надамо се да ће се након ревидирања наставних програма ситуација поправити. За наставнике би било значајно, а за ученике веома подстицајно, када би постојало више планираних часова посвећених стратегијама читања и провери читалачких компетенција. На тај начин би наставник био сигурнији да ће ученици савладати предвиђене стандарде из области вештине читања. То је од изузетне важности за полагање завршног испита и опште матуре ${ }^{1}$, с обзиром на то да су образовни стандарди основа ових испита.

Идеја о истраживачком пројекту из ове области проистекла је из непосредног рада са ученицима. Уочено је да ученици имају одређене предрасуде када су тестирања и оцењивања у питању. Навикнути углавном да на тесту треба да покажу шта су запамтили и научили, често се осећају збуњено када се од њих не тражи да покажу стечено знање, него да покажу на који начин размишљају или да управљају информацијама које су им дате. Пре почетка теста, ученицима је наглашено да се не тестира стечено знање, већ способност да пронађу одређене информације, да уоче узрочно-последичне везе, да упореде два текста, итд. То значи да се све информације које су потребне за израду теста, већ налазе у њему и да само треба пажљиво читати. Ученици у први мах помисле да су захтеви који им се постављају превише лаки. Фаворизујући приступ у коме се вреднује памћење чињеница, често не успевају да одоле томе да ипак покажу своје предзнање на тесту читалачких компетенција. То се показало тачним и при анализи овог теста.

${ }^{1}$ Општа/уметничка матура се управо уводи у образовни систем Републике Србије. Иако још увек није прецизирана концепција испита, извесно је да ће се задаци заснивати на образовним стандардима. 


\section{2. СРЕДЬОВЕКОВНА КЮИЖЕВНОСТ КАО ПОЛАЗИШТЕ ТЕСТИРАЮА}

Осмишљен је тест који могу радити ученици свих разреда средње школе, како би се пратио развој читалачких компетенција на различитим узрастима. Изазов је био осмислити тест који није превише тежак ученицима првог разреда нити превише лак ученицима четвртог разреда. Основна идеја је била да се задаци заснивају на сложенијим полазним текстовима. На тај начин би задаци били изазовни за ученике виших разреда, док би се могли уочити проблеми са којима се сусрећу ученици нижих разреда. Мноштво је критеријума који утичу на сложеност текста. Развијеност синтаксичких структура, специфичности лексичког фонда и особености тематско-мотивског склопа, само су неки од њих. Стога је било погодно да се задаци осмисле на књижевим делима из неке раније књижевне епохе. Средњовековни текстови представљају веома изазован корпус за тестирање ученичких компетенција. Синтаксичке структуре су често неуобичајене за савремени језик, јер се у преводима тежило очувању духа српскословенског језика. Морфолошке структуре су такође знатно сложеније него у савременом језику. Јављају се многе сложенице које су у савременом језику непознате или ретке, што се може приказати и на примерима са овог тестирања (човекољубаи, земьемерије, златоседлани, крстозначни, самодржаи, доброразумье, свеплеменити, многомирисана). Лексички корпус средњовековних дела свакако је веома комплексан, а тематика углавном није блиска искуствима савременог читаоца. Сви наведени фактори утичу на перцепцију текста.

Ученици се упознају са поетиком средњовековне књижевности у другом полугодишту првог разреда. Предвиђено је дванаест часова за обраду и утврђивање наставних јединица из ове области у гимназијама свих смерова, док је у средњим стручним школама предвиђено једанаест часова. Сматра се да у том периоду ученици могу да овладају поетиком средњовековне књижевности у довољној мери. Како би се могли обухватити различити аспекти сазнајних и когнитивних процеса, тестирање је извршено у децембру, када ученици првог разреда још нису били упознати са поетиком средњовековне књижевности. Тако се могло анализирати колико познавање поетике неке стилске формације утиче на разумевање текстова који јој припадају. Очекивало се да ће ученицима првог разреда израда задатака бити знатно отежана, јер се сусрећу са тематиком, сензибилитетом, као и лексичким и морфолошким конструкцијама које им нису довољно познате. У основној школи, ученици су се спорадично сусретали са делима средњовековне књижевности, али не довољно да стекну увид у поетичке одлике епохе. ${ }^{2}$

2 Програмом за седми разред предвиђена је обрада следећих наставних јединица: Свети Сава: Писмо игуману Спиридону, Свети Сава у књижевности (избор из Савиних 
Очекивано је да се читалачке компетенције ученика развијају са узрастом. Међутим, након овог тестирања можемо уочити и како ће задацима приступити ученици трећег и четвртог разреда, чије би опште читалачке компетенције требало да буду у великој мери развијене, али, са друге стране, постоји знатна временска удаљеност од проучавања поетике средњовековне књижевности. Један од кључних подстицаја за одабир оваквих текстова јесте запитаност колико културолошки и историјски контекст утиче на ваљаност разумевања текста.

Истакнути књижевни критичар и херменеутичар, Ерик Доналд Хирш истиче да је проблем што значење једног књижевног текста веома често постаје његово данашње значење за нас. Извесни текстови би могли, услед тога што су настали у ранијим епохама, да представљају ауторска значења која су данас недоступна. Променљиве културолошке околности свакако доводе до мењања значења текста. Претпоставља се да се перцепција одређених садржаја мења када се околности измене и да је некад тешко реконструисати сва семантичка поља која је текст покретао у времену свог настанка. Међутим, Хирш сматра да и поред тога што су нам значења прошлости суштински страна и што нам нису аутентично доступна, не значи да истински не можемо разумети и протумачити неки стари текст (Хирш, 1983). За младе читаоце је изузетно важно да се сусрећу и са текстовима сложенијим за тумачење, који додатно могу развити њихове стратегије читања, али и начине поимања света. Хирш истиче да је главни разлог за изучавање старих текстова чињеница да се код ученика развија дух упознавањем са понашањем и мишљењем некадашњих људи. Читаоци су тако у прилици да виде и осете оно што су други видели и осетили, да сазнају оно што су они знали. Много више развојних благодати ужива човек који се упознаје са духовним делатностима насталим у претходним епохама. Иако читање старих текстова за ученике представља својеврсни духовни времеплов, са мноштвом занимљивих сазнања, когнитивни процеси су нешто сложенији него при проучавању савремених текстова.

\section{3. КАРАКТЕРИСТИКЕ ТЕСТА ЧИТАЛАЧКИХ КОМПЕТЕНЦИЈА}

Међународним програмима тестирања читалачке писмености (као што cy: PISA, PIRLS, ALL, итд.) подиже се свест о значају читања за активно и критичко учествовање у друштву. Концепт доживотног образовања довео је до свеобухватнијег схватања појма писмености. Поред основног значења овог појма, данас се под писменошћу подразумева и склоп функционалних и

списа, народних прича и предања; народне и ауторске поезије о Светом Сави). Програмом за осми разред предвиђена је обрада наставне јединице: Теодосије, Житије Светог Саве (одломак). 
трансферних знања и умења које особе стичу током читавог живота кроз интеракцију у друштвеним групама. Дакле, поред елементарне, алфанумеричке писмености (која подразумева способности читања, писања и рачунања), према савременим концепцијама, овај појам обухвата и: функционалну, читалачку, библиотечку, информацијску, информатичку, друштвену, визуелну и медијску писменост.

Међународни програм процене образовних постигнућа ученика ПИСА (PISA - Programme for International Student Assessement) иницирала је Организација за економску кооперацију и развој (OECD) са циљем да се системски прати квалитет и праведност образовања у појединачним земљама учесницама. Програм ПИСА је данас један од најзначајнијих међународних програма у области образовања и једна од најважнијих смерница за образовну политику. У оквиру програма ПИСА систематски се прати који ниво функционалне писмености достижу петнаестогодишњаци у области разумевања прочитаног. Сматра се да је област разумевања прочитаног релевантан индикатор постигнућа ученика. Специфичност оваквог тестирања јесте да се не испитује у којој мери ученици могу да репродукују оно што су научили у школама, већ у којој мери су оспособљени да разумеју и користе информације приликом решавања задатака. Током тестирања проверавају се следећи мисаони процеси ученика: схватање смисла теста, проналажење информација у тексту, интерпретирање значења текста, рефлексија о садржају текста и евалуација. Очекује се од ученика да примењују аналитичко-синтетичке методе у решавању проблема.

Приликом процењивања вештине читања, важно је имати на уму Блумову таксономију когнитивних процеса, као и Гилфордове ставове о начинима размишљања. Банџамин Блум је описао шест нивоа когнитивних процеса (памћење, разумевање, примена, анализа, евалуација, креирање). Блумова таксономија нуди један начин посматрања изузетно комплексних когнитивних способности. Џој Пол Гилфорд је установио другачији поглед на когнитивне процесе, описујући конвергентни и дивергентни начин размишљања. За когнитивне процесе који подразумевају конвергентно размишљање најпогодније је писати задатке затвореног типа, пре свега задатке вишеструког избора. Ови задаци подразумевају предвидљив одговор, па је стога најпогодније користити форму задатка који се лако прегледа и чији се резултати могу лако анализирати. Задаци који имају за циљ да активирају дивергентно размишљање ученика најбоље се тестирају задацима отвореног типа, пре свега оним задацима који подразумевају продужени или есејски одговор. Такви одговори подразумевају синтезу или евалуацију.

На тестовима читалачких компетенција формулишу се задаци засновани на линеарним и нелинеарним типовима текстова. Овом приликом, спроведено је тестирање на линеарном типу текстова. Стандардизовани тестови који се спроводе у нашем обрзовном систему (завршни испит, 
иницијални тестови) служили су као оријентир и модел у припреми овог тестирања.

\section{4. ОРГАНИЗАЦИЈА И СПРОВОЪЕЬЕ ТЕСТА}

Тестирање је спроведено у децембру 2017. године у Првој београдској гимназији. Тестирано је по једно одељење првог, другог, трећег и четвртог разреда. Тестирање је било најављено, а ученицима је сугерисано да би било добро да буду присутни у пуном саставу. Тестирању је приступило укупно 116 ученика.

Ученици Прве београдске гимназије упознати су са начинима и циљевима тестирања читалачких компетенција неколико дана пре израде теста. Усмено су, током редовног часа, припремљени на тест ситуацију која им предстоји. Кратке смернице за рад добили су и пре почетка тестирања, док је на сваком примерку теста на почетној страни било одштампано упутство за рад. Ово упутство је преузето са насловне стране завршног испита и модификовано за ову прилику.

Оптимално време за израду теста утврђено је пилот-тестирањем. Осмишљени тест састоји се од петнаест задатака. С обзиром на знатан број задатака отвореног типа, али и на сложеност полазних текстова, није било лако проценити које је оптимално време за израду теста. Стога је спроведено пилот-тестирање на мањем узорку ученика друге школе. Резултати су указали на то да је 90 минута оптимално време за израду задатака.

\section{5. ОПИС СТРУКТУРЕ ТЕСТА ПРЕМА НИВОУ ПОСТИГНУЋА И ТИПУ ЗАДАТКА}

Пре састављања теста, подробно је испитана концепција и сврха екстерних тестова у нашем просветном систему (као што су завршни испит, пробни испит, иницијални тест) стога што они представљају одређени стандард квалитета коме би требало тежити и приликом других тестирања. Проучена су и национална истраживања која су вршена у неким разредима основне школе, али и међународна тестирања, од којих је најпознатији пројекат ПИСА.

Процес израде теста био је поступан и темељан. Задаци су усаглашени са образовним стандардима за крај средњошколског образовања. Спецификације теста прилагођене су узрасту ученика и очекиваној развијености апстрактног мишљења. ${ }^{3}$ Конструкције употребљених језичких садржаја пажљиво су одабране.

${ }^{3}$ Спецификације су првенствено усаглашене са развојним способностима ученика четвртог разреда средње школе, пре свега зато што се тест заснива на образовним стандардима за крај средњошколског образовања. Како још увек немамо образовне 
Тест се састоји од петнаест задатака, од чега је пет задатака основног, пет средњег и пет напредног нивоа. Како би тест био уједначен по типовима задатака, у тест је уврштено осам задатака затвореног и седам задатака отвореног типа. Различити типови задатака испољавају предности и мане како у процени знања тако и у процесу прегледања. Задаци затвореног типа су погодни за прегледање, али са друге стране, не пружају увид у стратегије решавања задатка. Од задатака затвореног типа најчешће су коришћени задаци вишеструког избора, који су погодни због своје објективности и економичности. У задацима отвореног типа ученици самостално креирају одговоре, чиме се некад може пратити процес решавања задатака. Неки одговори упућују на когнитивне процесе ученика, посебно онда када ученици образлажу свој став. Управо зато што ученици сами конструишу одговоре, очекују се врло различити типови одговора и различити погледи у односу на постављено питање. Када су у питању екстерна тестирања, задатке отвореног типа морају прегледати посебно обучени предметни стручњаци, док задаци затвореног типа могу да се прегледају и посредством компјутерских програма који су за то предвиђени.

\section{6. АНАЛИЗА ТЕСТА}

Тест читалачких компетенција, са спецификацијом и упутством за прегледање, биће дат у прилогу рада, у циљу илустрације појава о којима говоримо.

Прва четири задатка ослањају се на полазни текст Сказање o писменима, чији је аутор Црноризац Храбар. Овај текст је био погодан за тестирање из неколико разлога. Првенствено због свог обима, односно могућности да се изложи у целости, чиме су се могли искористити многи његови семантички потенцијали. Текст је конципиран као филолошка расправа, што је истакнуто у инструкцији за читање текста. На тај начин ученицима је скренута пажња да приликом читања размишљају о разлозима за полемичко наступање аутора. Првим задатком се проверава да ли ученици разумеју основни смисао текста. Да би схватили опште значење, важно је да добро размотре текст и да селектују информације. У другом задатку се проверава да ли ученик може да препозна смисао и значење текста. Важно је да ученик уочи намеру аутора, односно да схвати према коме је усмерен полемички тон. Трећи задатак захтева поновно читање, претраживање теста,

исходе за крај сваког разреда, образовни стандарди за крај одређених циклуса могу бити добар показатељ чему ученици млађих разреда треба да теже. Водило се рачуна о томе да задаци не буду претешки ученицима првог разреда средње школе, а ни превише лаки ученицима четвртог разреда. У оваквој тест ситуацији, сложеност задатака зависила је од ученичког лексичког фонда, од познавања поетике стилске формације, као и од читалачких навика. 
проналажење релевантних информација и попуњавање места недоречености. С обзиром на то да се од ученика тражи информација која није експлицитно наведена, ученик пре свега мора да препозна значај неког податка за информацију која се тражи. У четвртом задатку ученик треба да препозна речи којима аутор исказује своју пристрасност или суптилну тежњу ка убеђивању читаоца.

Као полазни текст за пети задатак узет је одломак из средњовековног романа Варлаам и Joacaф, који припада књижевној традицији древног Истока. У романескну грађу су уткане кратке алегоријске приче. Оне се могу читати самостално јер не зависе од фабуле романа. Једна таква целина је прича о славују, која је погодна за испитивање читалачких компетенција из више разлога. Пре свега, у њој се испољавају многе поетичке одлике средњовековне књижевности. Са друге стране, погодна је за прављење задатка због своје сажетости. Пети задатак подразумева рефлексију о садржају текста и евалуацију. Потребно је да ученик ваљано размотри текст и да вреднује његов садржај, да процењује заснованост изнетих чињеница, да уочава противречности, да анализира аргументе и контрааргументе за постављени проблем. Важно је и да се смислено уобличи и изнесе став. Оваквим задацима активира се способност апстрактног размишљања код ученика. Задатак је вишеструко комплексан јер се тачним одговором подразумева укључивање неколиких когнитивних процеса.

Шести и седми задатак заснивају се на одломку из Житија Светог Симеона. Оба задатка према класификацији припадају напредном нивоу, који је пре свега условљен сложеношћу текста. Од свих примера који су одабрани за полазне текстове у овом истраживању, ученицима је најсложенији за разумевање текст овог житија. Без познавања поетике средњовековне књижевности ученици веома тешко могу разумети суштину и смисао одломка. Да би се текст исправно протумачио, потребно је бити упућен у основна начела и погледе на свет средњовековног човека. Читалац треба да препозна топос афектиране скромности и да увиди како скрушеност не потиче од недостатка самопоуздања или љубави према себи, већ да је то део комплексног религијског осећања. Упућени читалац ће лакше препознати функцију библијских цитата у карактеризацији ликова. Стога је са правом очекивано да ће ова два задатка представљати потешкоћу ученицима првог разреда, који нису упознати са поетиком средњовековне књижевности. Шести задатак свакако је лакши од наредног, јер је конструисан у затвореној форми, као вишеструки избор. Од ученика се очекује да функционално примене податке који су им дати. Седми задатак састоји се из два дела. У првом делу се проверава да ли ученик на ваљан начин интерпретира значења текста. Док открива значења текста, ученик треба да истовремено закључује и о информацијама или идејама које нису експлицитно дате. Извођење закључака треба да помогне ученику да иде даље од дословне интерпретације текста и да попуни празнине, неизвесности у значењу. Да би ученик могао да донесе 
потребне закључке, потребно је да паралелно оперише са више експлицитно или имплицитно датих информација. У другом делу задатка се проверавају следећи когнитивни процеси: рефлексија и евалуација форме текста. У класификацији која се користи за потребе ПИСА тестирања, размишљање о форми текста сматра се најсложенијим когнитивним процесом којим ученик треба да овлада. Овакав захтев проверава се питањима отвореног типа у којима се од ученика тражи да објективно и критички разматра форму текста, његову структуру, жанр, начин и стил писања. У овом задатку ученик треба да размотри стил писања и да одговори која је функција тога што аутор о себи говори у трећем лицу.

Наредних пет задатака као полазни текст имају Натпис на косовском мраморном стубу. У инструкцији за читање, ученици су упознати са основним информацијама у вези са овим текстом. Форма осмог задатка је таква да се од ученика очекује кратак одговор. Међутим, то не значи да су ученички одговори лако предвидљиви. Као и увек када су у питању задаци отвореног типа, распон могућих одговора је велики. С обзиром на то да информација која се од ученика тражи није исказана експлицитно, ученик треба да закључи која информација из текста је релевантна за решавање задатка.

На примеру деветог задатка може да се прикаже колико су задаци отвореног типа захтевни за прегледање. Чак и онда када подразумевају кратак одговор, потребно је да прегледачи буду добро обучени како би се уједначио критеријум и избегла произвољност. Због тога је, када су у питању стандардизовани тестови које оцењује велики број прегледача, потребно да се прецизно дефинишу критеријуми прихватљивих и неприхватљивих одговора и да се наведе што већи број могућих ученичких одговора. Десети задатак подразумева проналажење експлицитне информације у тексту. Нема празнина у значењу текста које би требало надоместити, значење је евидентно и јасно назначено, па није потребно да ученик било шта закључује. Управо стога, овај задатак према класификацији припада основном нивоу. У једанаестом задатку се препознаје радни налог који се ученицима даје још од млађих разреда основне школе. Потребно је да се текст подели на одређене смисаоне, тематске целине, па да се потом именује свака од њих. Да би ово постигли, ученици треба прво да у свести резимирају текст, како би издвојили најважније делове од којих је конструисан. Постоји, наравно, више начина да се тачно одговори на овај захтев. Од ученика се не тражи униформисаност у одговарању, остављена им је велика слобода у креирању одговора. Важно је да издвојене тематске целине буду засноване на тексту. Дванаестим задатком се испитује да ли ученик разуме намеру аутора. Ученик треба да процени на који начин се постиже ефекат аутентичности текста. У тринаестом задатку се од ученика тражи да размотри наведене тврдње и да се одлучи за оне које се односе на текст. 
Последњи текст са којим се ученици сусрећу на овом тестирању јесте поучни спис Физиолог. У наредна два задатка ученици читају приче из овог касноантичког списа, који је преко византијске традиције постао део и српске средњовековне баштине. Ученици су у краткој наративној форми упознати са природом овог списа, како би им решавање задатака било олакшано. Истакнуто је да свака прича има истоветну стуктуру. Први део је алегоријски интониран, а односи се на неку животињу, биљку или камен. У другом делу се разјашњава алегоријско значење и праве се аналогије са људским животом. У задатку је дат први део приче која се назива Слово о орлу, а након тога алегоријско тумачење три различите приче, али без наслова. Ученик треба да препозна које се тумачење односи на ову причу, одоносно да пронађе други део приче о орлу. Физиолог је погодан за овакве врсте тестирања, с обзиром на то да су приче које садржи кратке, елиптичне, али семантички вишеслојне и богате. Од ученика се захтева да пореди информације и идеје из четири наведене целине и да доноси закључке о аналогијама. Дистрактори су такође преузети из Физиолога, како би тематски и стилски били уклопљени са тачним одговором. Они представљају тумачења алегоријског смисла прича: Слово о детлићу и Повест о сунчаном гуштеру. У тестовима читалачких компетенција честа је пракса да се испитаницима дају кратки текстови са нарушеном структуром. Интервенције на првобитном тексту могу подразумевати: премештање наслова са почетка на крај, уклањање наслова или премештање реченица унутар текста. За ову прилику искоришћена је последња од набројаних могућности. Да би ученици открили првобитни распоред реченица потребно је да уочавају узрочно-последичне везе и да обраћају пажњу на текстуалне конекторе. Истакнуто је пет реченица из приче Слово о јелену и змији, која такође припада поучном спису Физиолог. Ради боље прегледности и лакше израде истакнуто је која је реченица прва.

Када су у питању задаци вишеструког избора, важно је нагласити да је посебна пажња посвећена дистракторима. Водило се рачуна да дистрактори имају логичку везу са полазним текстом, али да не представљају ни делимично тачан одговор на постављено питање. Стога се може десити да након површног читања ученику дистрактор делује као тачан одговор. Управо је сврха оваквих тестирања да подстичу ваљано читање и разликовање важних и неважних информација у тексту.

Анализом резултата теста уочено је да ученици првог разреда са изненађујућим успехом решавају задатке затвореног типа. У многим случајевима, када је ова врста задатака у питању, ученици првог разреда су знатно успешнији од старијих ученика. То је свакако неочекивано, нарочито стога што ученици првог разреда нису упознати са поетиком средњовековне књижевности. Поставља се питање да ли су старији ученици мање мотивисани за израду теста или постоје неки други ометајући фактори. За процену овог проблема била је од велике помоћи ученичка евалуација задатака. Млађи ученици су истакли да су им од велике помоћи биле сличне форме задатака 
приликом вежбања за завршни испит. Када су у питању задаци отвореног типа, уочавамо знатно већу успешност старијих ученика, што указује да се способност вербализације мишљења повећава са узрастом.

\section{7. АНАЛИЗА ЗАДАТАКА ПРЕМА ОЧЕКИВАНИМ НИВОИМА ПОСТИГНУЋА}

Како би се стекла целовитија слика о резултатима теста, графички су приказана постигнућа ученика по разредима за сваки задатак понаособ, а задаци су груписани према очекиваним нивоима постигнућа.

\section{1. Основни ниво}

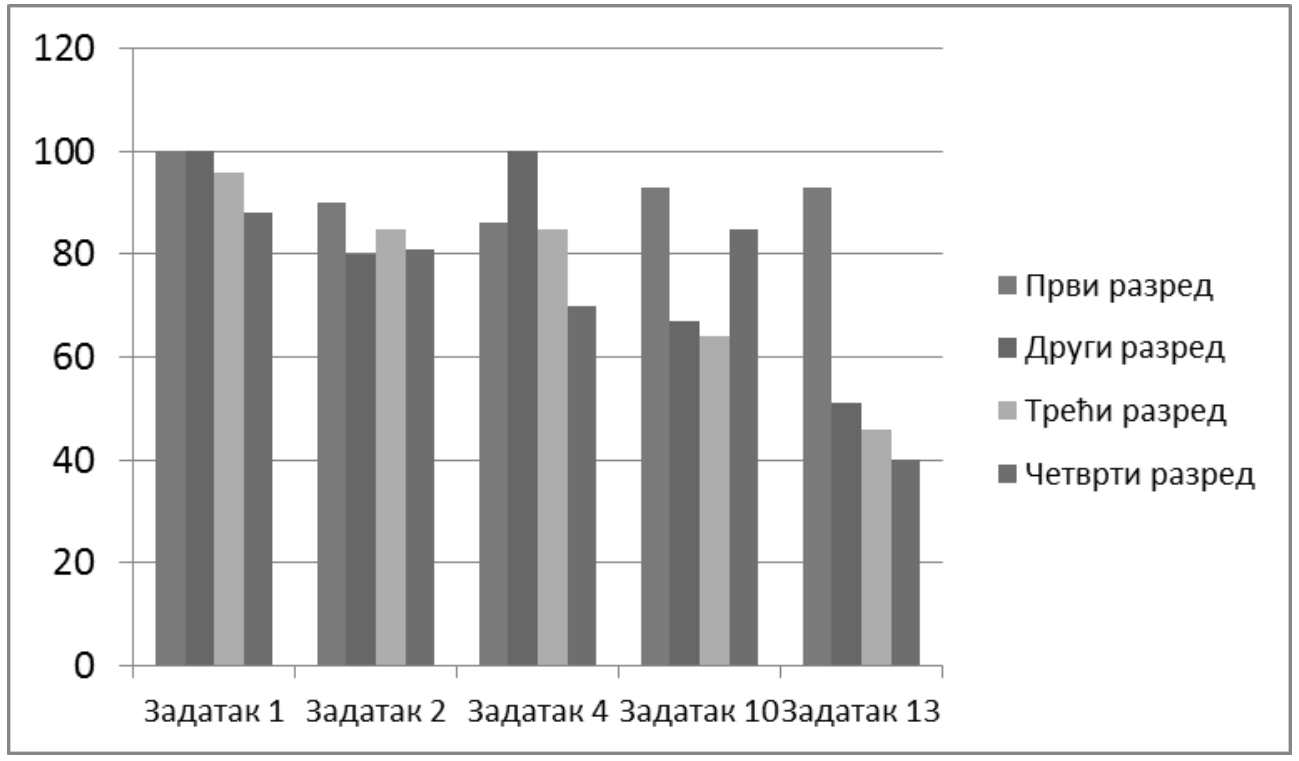

Графикон 1. Резултати задатака основног нивоа

Када проучимо график, уочавамо пре свега неочекиване резултате тестирања у првом разреду. Јасно је да непознавање поетике средњовековне књижевности није знатно утицало на разумевање задатака са основног нивоа. Занимљиво је напоменути да су на основном нивоу, у свим задацима сем четвртог, ученици првог разреда остварили најбоље резултате. Оваква постигнућа нису била очекивана. Не поставља се само питање шта је то ученицима првог разреда олакшало израду задатака, већ и питање из ког разлога су ученици виших разреда постигли слабије резултате.

Очигледно је да разумевање смисла претходи тумачењу. Задаци са основног нивоа конципирани су тако да се ослањају на два полазна текста: Сказање о писменима и Натпис на косовском мраморном стубу. Ученици су, 
свакако, и поред одређене сложености текстова, непознатих речи и специфичне морфолошке и синтаксичке структуре, ваљано протумачили смисао текста. Радни налози ових задатака ученицима су блиски још из основне школе, а нарочито из периода припреме за завршни испит. Сви задаци са основног нивоа су затвореног типа, осим десетог, који захтева кратак одговор. Уочава се да ученици имају великог успеха у решавању задатака затвореног типа, као што је и очекивано.

\section{2. Средњи ниво}

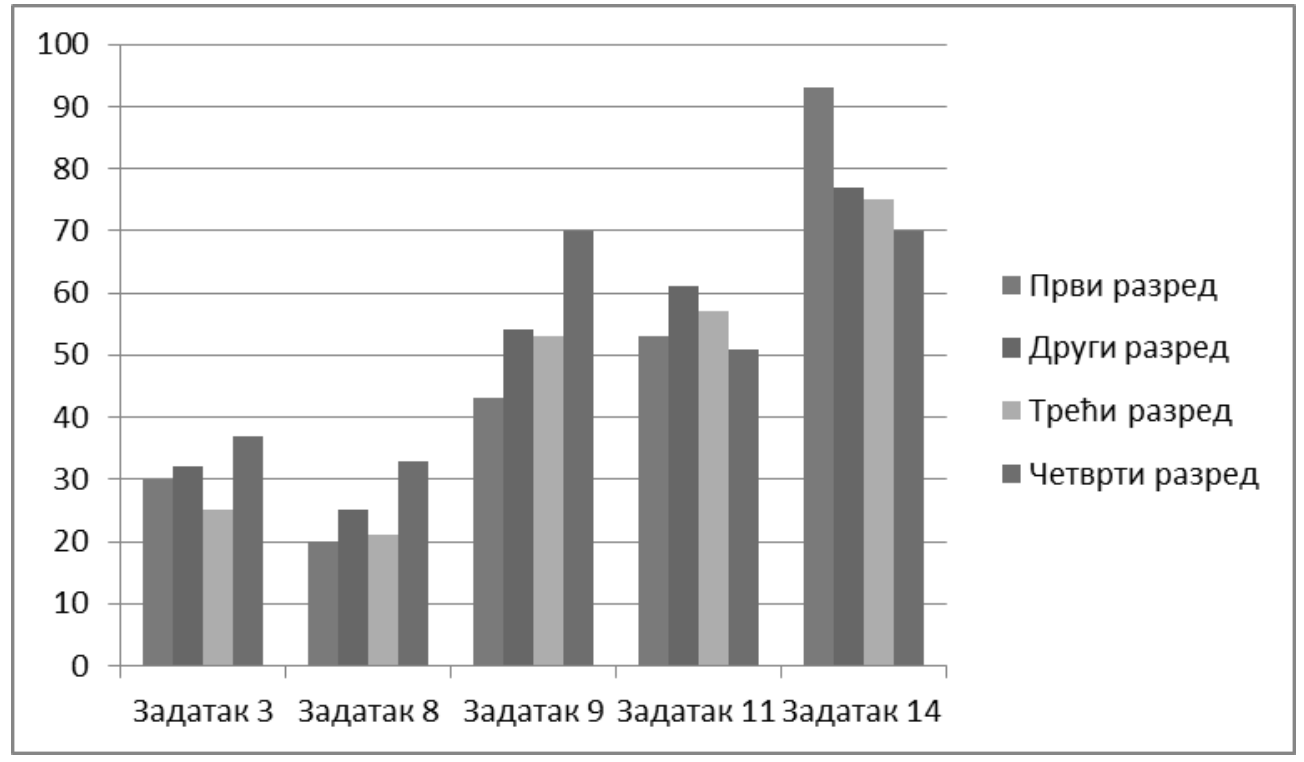

Графикон 2. Резултати задатака средњег нивоа

Када се упореде подаци са графика, уочава се да су трећи, осми и девети задатак најбоље урадили ученици четвртог разреда. То је било и очекивано, јер се подразумева да се читалачке компетенције развијају са узрастом. Једанаести задатак најбоље су урадили ученици другог разреда, док су у решавању четрнаестог задатка највише успеха имали ученици првог разреда. Сви поменути задаци осим четрнаестог су задаци отвореног типа. Уочавамо да у задацима вишеструког избора ученици првог разреда постижу веома добре резултате, док су у решавању задатака отвореног типа знатно успешнији старији ученици. На основу овога, може се извести закључак да се моћ вербализације мисаоних процеса развија са узрастом. Оваквом мишљењу у прилог иде и чињеница да је проценат непопуњених задатака отвореног типа знатно већи у нижим разредима, пре свега у првом. Важно је нагласити да се у задацима отвореног типа није вредновала правописна и граматичка 
исправност, што би такође могло утицати на знатно боље резултате старијих ученика.

\section{3. Напредни ниво}

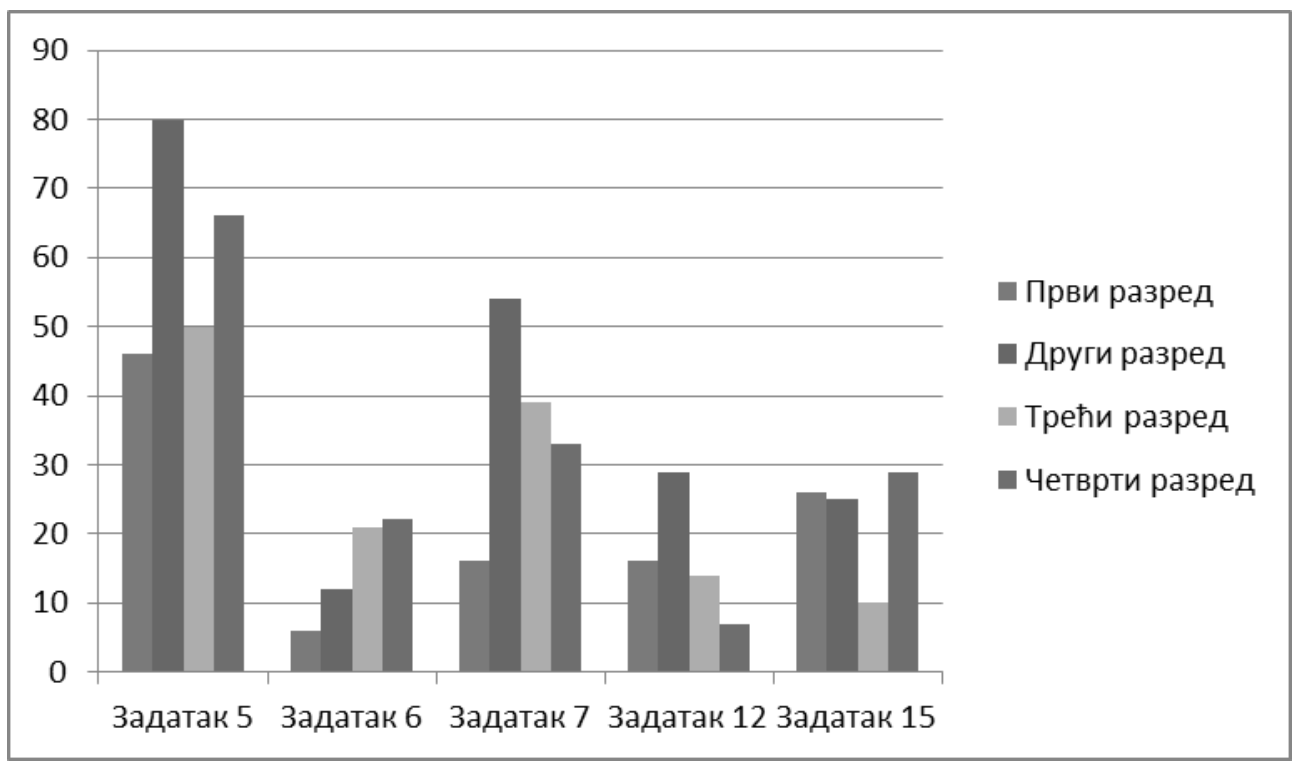

Графикон 3. Резултати задатака напредног нивоа

Када се анализирају задаци са напредног нивоа, изводи се закључак да је познавање поетике било изузетно важно за успешно решавање. Ученици којима су била најсвежија знања о средњовековним текстовима, односно ученици другог разреда, са великим успехом су решавали скоро све задатке напредног нивоа. Пети, седми и дванаести задатак убедљиво су најбоље урадили ученици другог разреда. Подсетимо, у тренутку када су приступили тестирању, прошло је нешто мање од годину дана од обрађивања дела из средњовековне књижевности. Ученици трећег разреда су у нешто неповољнијем положају - протекле су две године од њиховог последњег сусрета са средњовековном књижевношћу, док су код ученика четвртог разреда протекле три године од тог тренутка. Са друге стране, ученици четвртог разреда су на часовима књижевности и језика највише развили опште читалачке компетенције, па су стога у повољнијој позицији у односу на млађе ученике. Уочавамо да постоји доста фактора који утичу на ваљано разумевање текста и израду задатака. Када се посматрају резултати теста у целости, зачуђују веома добра постигнућа ученика првог разреда. То није било очекивано из два разлога. Првенствено зато што они нису упознати са поетиком средњовековне књижевности, па им разумевање смисла може бити отежано, а потом и стога што се подразумева да су њихове опште читалачке 
компетенције на нижем нивоу од старијих ученика. С обзиром на ограничења теста као мерног инструмента, којим се не могу испитати стратегије читања, стратегије решавања задатака, недоумице са којима се ученици сусрећу итд., осмишљен је упитник који ученици треба да попуне након теста. Циљ састављања упитника је да се уочи шта је ученицима олакшавало, а шта отежавало израду задатака. На тај начин се донекле могу објаснити добијени резултати.

\section{8. УЧЕНИЧКА ЕВАЛУАЦИЈА ТЕСТА}

Резултати упитника укрштени су са усменим одговорима, с обзиром на то да је један час посвећен анализи теста и дискусији са ученицима. Свакако је корисно размотрити које су технике ученици примењивали приликом решавања теста и на какве су проблеме наилазили.

Као најлакше задатке ученици су издвајали задатке са основног нивоа, што је било очекивано и у складу са резултатима. Као најтеже задатке ученици су означавали задатке отвореног типа, у којима је требало да разложно и ваљано образложе своје тумачење текста. Уочава се, такође, да су ученици старијих разреда са већом лакоћом и успешношћу решавали задатке отвореног типа.

Ученицима је наглашено да није потребно предзнање за израду оваквих задатака, већ да су све релевантне информације садржане у тексту. Многи су ипак сматрали да је предност уколико покажу и предзнање. То је углавном доводило до погрешних решења у задацима, јер су се ослањали на асоцијативне везе стечене током претходног школовања, а не на логичку структуру текста. Тумачећи Житије Светог Саве неки ученици наводе историјске податке о Савином односу са браћом, који нису утемељени у овом тексту и тако долазе до погрешних тумачења. Са Косовском битком неки ученици повезују Милоша Обилића, као истакнутог јунака епске традиције, који се, међутим, у тексту не помиње. ${ }^{4}$ Ипак, асоцијативна веза између Косовске битке и Милоша Обилића толико је јака да је ученици активирају и онда када у тексту не постоји утемељеност за то.

Анализом упитника се закључује да ученици нису навикнути да читају много текста како би решили задатак, потом да читају брзо и површно. Много више стрпљења и истрајавања у изради оваквих задатака имају ученици првог разреда. Како су сами истакли у анкети и током дискусије, они се осећају припремљено за израду оваквих задатака, јер су радили доста сличних вежбања приликом припреме за завршни испит. Завршни испит има сертификациону, селекциону и евалуациону функцију и умногоме утиче на будућност ученика. Стога му они приступају са великим залагањем. Збирка

\footnotetext{
${ }^{4} \mathrm{y}$ питању је Натпис на косовском мраморном стубу.
} 
задатака за припрему завршног испита подељена је у три поглавља, у којима се налазе задаци основног, средњег и напредног нивоа. Свако од поглавља је подељено на четири области: вештина читања и разумевање прочитаног; писано изражавање; књижевност; граматика, лексика, народни и књижевни језик. То значи да се сви ученици осмог разреда сусрећу са мноштвом задатака који проверавају вештину читања. Изгледа да је управо то фактор који је утицао на изузетно добре резултате ученика првог разреда. Ученици старијих разреда нису се више сусретали са тестовима из вештине читања. Они нису планом и програмом предвиђени као активности вежбања или провере знања. Ученици виших разреда су удаљенији од полагања завршног испита, стратегије решавања оваквих задатака нису им толико блиске. Често наводе да им је тест неуобичајен, превише лак (што резултати не потврђују), или превише тежак услед непознатих инструкција. Све ово показује да је за ученике виших разреда ово готово непозната тест ситуација. Претпостављамо да ученици виших разреда имају развијеније опште читалачке компетенције, а притом су и упознати са поетиком средњовековне књижевности. Ипак, у многим случајевима сва та преимућства ученици првог разреда успевају да надмаше, и то само зато што су добро обучени да решавају задатке из вештине читања. Уочава се велика потреба да се развијању и тестирању читалачких компетенција посвети много више пажње, првенствено у наставним плановима и програмима, а потом и у наставној пракси. Показује се да су и ученици другог разреда били веома успешни у изради теста. У дискусији и прегледањем анкете испоставило се да су полазне текстове сматрали једноставнијим и мање захтевним од осталих ученика, јер су се са одређеним бројем сличних текстова срели у релативно блиском периоду. Такође, вежбања за завршни испит која се тичу вештине читања нису им далека као старијим ученицима. Ученици трећег и четвртог разреда жалили су се на форму задатака, на радне налоге и на сврху оваквог тестирања. Сматрали су да је сврсисходније радити традиционалне тестове из језика и књижевности. Многима је деловало да је превише лак тест који не проверава знање него вештину, али су након анализе резултата били заинтригирани и желели су поново да се опробају у сличној врсти теста. Ученици првог разреда су наводили велики број непознатих речи, што је било и очекивано. Ученици другог разреда издвајали су знатно мање непознатих речи, а као коментар наводили су често да и оне речи које су им мање познате лако успевају да надоместе ослањајући се на контекст. Чини се да ученици при савладавању неке удаљеније стилске формације усвајају и стратегије читања и разумевања текстова (веома често са попуњавањем празнина у тексту). Занимљиво је да на ово питање у анкети слично одговарају и старији ученици, што значи да вештина тумачења старих текстова постаје трајно умење ученика.

У дискусији након тумачења задатака, ученици истичу жељу да се чешће опробају у изради оваквих тестова. Уочава се да ученици осећају 
велики изазов да реше задатке оваквог типа и да увежбавају логичко промишљање текста. Симптоматично је да ученици који су истицали једноставност теста по правилу остваре лоше резултате. Вероватно је то стога што се не препусте продубљеном и аналитичком размишљању. Међутим, управо такви ученици показују највећу жељу да се што пре опробају у новим изазовима за решавање из ове области. Вредно је напоменути и то да ученици наглашавају да би волели да раде више оваквих тестова јер сматрају да су им корисни не само за професионални развој, већ и за сваки други сегмент живота. Јасно је да ученици увиђају важност овладавања читалачким вештинама за концепт целоживотног учења, али и за успешно и активно учешће у друштву.

\section{9. ЗАКљУЧАК}

Спроведено истраживање представља скроман прилог наставној пракси у коју се могу укључити тестови вештине читања у разним облицима. Читалачке компетенције ученика развијају се и снаже на сваком часу књижевности. Ипак, постоји потреба да се више пажње посвети томе како ученици разумеју и тумаче одређено књижевно дело, без намере да се испитају њихова књижевнотеоријска и књижевноисторијска знања. Вештина разумевања прочитаног је базични предуслов за постизање резултата у било ком предмету у школи. Стога је то компетенција која има високу вредност у свим областима стручног рада, али и свакодневног живота. Драгоцене смернице за наставнике представљају национални стандарди знања, вештина и компетенција којима ученици треба да овладају у свакој области. Увођењем опште и уметничке матуре у средње школе свакако ће се посветити већа пажња примени образовних стандарда у средњој школи. Потребно је, такође, и планирање већег броја наставних садржаја који имају за циљ развијање читалачких вештина на најефикаснији и најприкладнији начин. Било би добро када би постојао већи број стандардизованих инструмената за проверу и праћење развоја читалачких компетенција. У овом тренутку, наставницима од највеће помоћи могу бити образовни стандарди, као и екстерни тестови за проверу знања и умења из разних области нашег предмета. То су, као што је већ поменуто, завршни испит и иницијални тест, који осмишљавају посебно обучени стручњаци из Завода за вредновање квалитета образовања и васпитања. То је стандард квалитета коме треба да тежи сваки наставник приликом осмишљавања инструмената за проверу разумевања прочитаног. 


\section{ЛИТЕРАТУРА}

Васић, С. (1994). Психолингвистика. Београд: Институт за педагошка истраживања. [Vasić, S. (1994). Psiholingvistika. Beograd: Institut za pedagoška istraživanja]

Гвозденовић, В. (2015). Теоријски и примењени аспекти психологије читања. Београд: Центар за примењену психологију. [Gvozdenović, V. (2015). Teorijski i primenjeni aspekti psihologije čitanja. Beograd: Centar za primenjenu psihologiju]

Јовановић, Т. (2012). Хрестоматија средњовековне књижевности. Старословенска и преводна књижевност. Београд: Филолошки факултет. [Jovanović, T. (2012). Hrestomatija srednjovekovne književnosti. Staroslovenska i prevodna književnost. Beograd: Filološki fakultet]

Јовановић, Т. (2012). Хрестоматија средњовековне књижевности. Српска књижевност. Београд: Филолошки факултет. [Jovanović, Т. (2012). Hrestomatija srednjovekovne književnosti. Srpska književnost. Beograd: Filološki fakultet]

Лаловић, Д. (2012). Читање: од слова до текста. Београд: Филозофски факултет. [Lalović, D. (2012). Čitanje: od slova do teksta. Beograd: Filozofski fakultet]

Николић, М. (2006). Методика наставе српског језика и књижевности. Београд: Завод за уџбенике и наставна средства. [Nikolić, M. (2006). Metodika nastave srpskog jezika i književnosti. Beograd: Zavod za udžbenike i nastavna sredstva]

Павловић, М. (2013). Књижевност у првом разреду гимназија и средњих стручних школа. Београд: Клет. [Pavlović, M. (2013). Književnost u prvom razredu gimnazija i srednjih stručnih škola. Beograd: Klett]

Радоњић, С. (1985). Психологија учења. Београд: Завод за уџбенике и наставна средства. [Radonjić, S. (1985). Psihologija učenja. Beograd: Zavod za udžbenike i nastavna sredstva]

Трифуновић, Ђ. (1990). Азбучник српских средњовековних књижевних појмова. Београд: Нолит. [Trifunović, Đ. (1990). Azbučnik srpskih srednjovekovnih književnih pojmova. Beograd: Nolit]

Hambleton, R. (2005). Item Response Theory models for Dichotomous Data. Chichester: John Wiley \& Sons.

Хирш, Е. Д. (1983). Начела тумачења. Београд: Нолит. [Нirš, Е. D. (1983). Načela tumačenja. Beograd: Nolit] 
Ksenija V. Milovanović

University of Belgrade

Faculty of Philology

PhD Studies - Module Literature

EXAMINATION OF STUDENTS' READING COMPETENCES ON MEDIEVAL TEXTS

\section{Summary}

Reading comprehension is a cross-curricular skill from on the understanding of the each subject depends. Therefore, it has become a practice not to test what students can remember and reproduce, but to what extent they are able to apply their reading skills. For the purpose of this research, the testing of reading skills was conducted in the First Belgrade Gymnasium. Before assembling the test, attention was paid to the concept and purpose of external tests in our educational system (such as the final exam or the initial test) because they represent a certain standard of quality which we should strive for in other tests. We also studied domestic research studies as well as international tests, the most famous of which is the PISA project. The process of making the test was gradual and thorough. Tasks have been harmonized with educational standards for the end of secondary education. Test specifications are adapted to the age of the student and the expected development of abstract thinking. The same test was done by students of all grades and the development of competences at different ages was monitored. Testing was done before the students of the first grade were introduced to the poetics of medieval literature. It was therefore convenient to analyze how the knowledge of medieval poetics influenced the understanding of the texts that belong to it. In the first class the students were expected to accomplish worse results because they encountered less well-known semantic and grammatical structures. The analysis of the results showed interesting and unexpected connections between the age, the knowledge of the poetic qualities and the achievements on the test. The paper is accompanied by the test, a specification with educational standards and levels of achievement, a graphical representation of achievement by age, and a student evaluation of the test. Such tests are useful not only for professional development, but also for other segments of life. Students recognize the importance of mastering reading skills for the concept of lifelong learning, but also for a successful and active participation in society.

Key words: reading competencies, reading skills, medieval literature.

Примљено: 2. 5. 2018.

Прихваћено: 17. 9. 2018. 
Пажљиво прочитај текст прве словенске филолошке расправе (Сказање о писменима, Црноризац Храбар) па одговори на захтеве.

Раније, дакле, Словени не имаху књига, него цртама и резама цртаху и гатаху, јер беху пагани. Крстивши се, беху принуђени писати латинским и грчким писмом словенску реч без устројавања. Потом човекољубац Бог, који устројава све, и не оставља људски род без разума, него све разуму и спасењу приводећи, смиловав се на род словенски, посла им светог Константина Философа, названог Ћирила, праведног и истинитог човека. И створи им 38 слова, једна по изгледу грчког писма, а друга према словенским речима. Од првог почевши по грчком: они, дакле, алфа, а овај аз, од аза обоје поче. И као што они створише писмо угледајући се на јеврејска, тако и овај према грчким. [...]

Ако упиташ учене Грке: Ко вам је створио писмо, или превео књиге, или у које време, то ретки од њих знају. Ако ли упиташ учене Словене: Ко вам је створио писмо или превео књиге, то сви знају, и одговоривши кажу: Свети Константин, звани Ћирило, он нам писмо створи и преведе књиге, и његов брат Методије. Јер има још живих који су их видели. И ако упиташ у које је то време било, и то знају, и рећи ће да је било у време грчког цара Михаила, и бугарског кнеза Бориса, и моравског кнеза Растислава и панонског кнеза Коцеља, 6363. (863) године од створења целог света. ${ }^{5}$

1. Која је главна тема ове расправе?

а) Покрштавање словенских племена;

б) Сличности јеврејског и грчког језика;

в) Настанак првог словенског писма;

г) Живот моравског кнеза Растислава.

2. Коме је упућен полемички тон у тексту?

a) Полемички тон упућен је ученим Грцима, који не знају ко им је створио писмо.

б) Полемички тон упућен је Симониду, који је грчком писму приложио само два слова.

в) Полемички тон упућен је онима чији су се језици помешали при зидању Вавилонске куле.

г) Полемички тон упућен је Константину Филозофу, који је створио писмо од 38 слова.

5 Ученицима је био доступан текст у целости. Због обимности рада, текст је овом приликом дат у одломцима. 
д) Полемички тон упућен је онима који оспоравају употребу словенског писма.

3. Препиши из текста реченицу која указује на време када је написана ова филолошка расправа и образложи зашто си се одлучио/одлучила за ту реченицу.

А) Реченица:

Б) Образложење:

4. У издвојеном делу текста подвуци две речи на основу којих можемо закључити какав је ауторов став о онима који оспоравају словенско писмо.

А други мисле да је Бог сам створио писмо, а не знају шта говоре кукавни. И веле како је Бог заповедио да књиге буду на три језика, пошто у Јеванђељу пише: И беше даска написана јеврејски, латински и грчки, а словенски није ту. Зато мисле да словенске књиге нису од Бога. Шта њима да говоримо и шта да кажемо таквим безумницима.

Пред тобом је једна прича из средњовековног романа Варлаам и Jоacaф. Роман потиче из књижевне традиције древног Истока, а сачуван је и у српскословенским преписима. Прочитај причу, па одговори на захтев.

О славују

Кажу да је онај који се клања идолима сличан човеку лепитељу, који прави лепак од биља ловећи птице, и ухвативши једну од премалих птица, која се зове славуј, узима нож и хоће је заклати и појести. Славују беше дат људски глас и рече лепитељу:

Која ти је корист, о човече, ако ме закољеш, јер не можеш мноме своју глад утолити? Него, ако ме ослободиш уза, даћу ти три поуке. Ако их сачуваш, велику ћеш вајду имати у читавом свом животу.

Задививши се таквом његовом казивању, он му обећа да ће га уколико чује од њега нешто ново убрзо пустити из ропства. Обративши му се, славуј му рече: 
Никада не покушавај да имаш оно што не можеш добити. Не кај се ни због чега што је прошло. Никада не веруј невероватној речи ${ }^{6}$. Ове три поуке чувај и добро ће ти бити.

Зачудивши се човек добро сроченим и разумним речима, раздреши га и пусти у ваздух. А славуј хтеде да сазна да ли човек разуме снагу речи које му изговори и да ли извуче неку корист од њих. Рече му летећи по ваздуху:

O, човече, тешко твојој бесмисленој памети! О, какво благо данас изгуби, јер у мојој утроби има бисер, већи него нојево јаје!

Када ово чу лепитељ, обузе га туга, кајући се што му онај славуј утече из руку. И, покушавајући да га опет ухвати, рече му:

Дођи у мој дом и када те добро угостим, отпустићу те са чашћу.

5. Да ли је лепитељ усвојио три поуке које му је славуј пренео? Образложи свој став позивајући се на текст (обрати пажњу на сваку поуку посебно).

Прочитај одломак из Житија Светога Симеона, које је написао Свети Сава, па одговори на захтев.

Овај блажени господин наш Симеон имаше три сина. А један, најмлађи, не могу га назвати сином, већ робом, кога љубљаше више од свих, а и овај неодступно њему работаше. Јер овај као млађи међу браћом својом, и најмлађи, и, просто рећи, видевши своје природе немоћ и умножење грехова својих, учини као и блудни син, оставивши доброг оца и господина, и блажену матер, госпођу своју, и благородну, нећу рећи браћу, већ господаре своје, и обнажи све безумљем својим. И отиде у страну туђу далеко, жирујући са свињама, и њихове хране не насићаваше се, мртав би, и не оживе, изгубљен беше, и не нађе се. (Лк. 15, 24) Јер овога блажени отац господин Симеон зажеле ићи у Свету Гору, као пастир добри потражити јагње

${ }^{6}$ Реч у коју је тешко поверовати. 
одбегло, и узевши га на раме, принесе Оцу свом и својој жељи, и да од Бога награду прими устрањења ради од својих, и другу жељу срца свога да испуни и да нађе љубљено и заблудело своје јагње. И разгоревши се Духом, мољаше се Богу, овако говорећи:

Цару славе, једини бесмртни, Оче неба и крепости, и који промислом своје доброте ниједан човек не желиш да погине, већ сви да се спасу, (I Тим. 2, 4) не остави мене погинути! Јер знам да је милост твоја велика на мени и сада молим те, Владико, дај ми овај пут окончати!

6. Пред тобом су тврдње које се односе на поетичке одлике средњовековне књижевности. Заокружи слова испред оних одлика које уочаваш у претходном одломку.

а) Хвали се испосништво и одрицање од земаљских уживања.

б) Истиче се грешност и ништавност човека.

в) Наглашава се пролазност овог света и свега што је материјално.

г) Парафразирају се мисли из Библије.

д) Истиче се човекова окренутост ка Богу у најтежим тренуцима.

7. А) Позивајући се на текст, опиши на који начин Свети Сава говори о себи у наведеном одломку.

Б) Образложи због чега Свети Сава о себи говори у трећем лицу.

Пред тобом је Натпис на косовском мраморном стубу, који је настао између 1402. и 1404. године. Аутор овог натписа је деспот Стефан Лазаревић. Пажљиво прочитај текст, па одговори на захтеве. ${ }^{7}$

7 Ученицима је био доступан текст у целости. Овом приликом, због обимности рада, текст није приказан. 
8. Ко је лирски субјекат у овом натпису?

9. Коме се обраћа лирски субјекат?
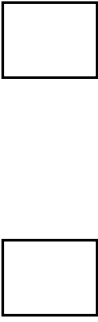

10. Позивајући се на информације изнете у тексту, напиши у ком материјалном облику (на ком материјалу) је првобитно записан овај текст.

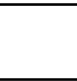

11. Издвој тематске целине заступљене у тексту.

12. Издвој реченицу којом аутор жели да постигне ефекат аутентичности натписа.

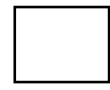

13. Заокружи слова испред тврдњи које се односе на Натпис на косовском мраморном стубу.

а) Велича се храброст и племенитост кнеза Лазара, који представља врхунац људске духовности.

б) Исказује се жеља за изградњом цркве на месту страдања, како би се одала почаст жртвама.

в) Истиче се многобројност турске војске, која им је омогућила надмоћ над српским војницима. 
г) Указује се на два аспекта борбе, први који подразумева овоземаљску победу и други који доноси небеску славу.

Физиолог је поучни спис касноантичке књижевности настао током 2. века у Александрији. У њему се кроз краће наративне целине о животињама, биљкама и камењу, алегоријски и са богатом симболиком говори о људима. Физиолог је у српској средини током средњег века радо читан и преписиван. Структуру прича чини први део, у коме се говори о некој животињи, биљки или камену, док се у другом делу објашњава алегоријско значење приче које се повезује са људским животом.

14. Пред тобом је први део једне приче из Физиолога, а након њега алегоријско тумачење три различите приче (без наслова). Твој задатак је да заокружиш слово испред оног алегоријског тумачења које се односи на ову причу.

Слово о орлу

Орао је, дакле, цар птица. Орлом га називају због многих његових узрока, јер он живи сто година. И када остари, порасте му и кљун и ослепи на очи и не може ловити и узлетати на велику висину. И стрмоглави се низ камен и разбије свој кљун. И купа се у Герусијем блату и седи према сунцу, те када му припече веома, спадају му као крљушти са очију и он постаје поново млад.

II

а) Помисли и ти, човече, да и ђаво долази на тебе са сваком нечистоћом и удара у тебе, а ухом ослушкује. Па ако будеш срчан у вери, побећи ће ускоро од тебе. Ако ли будеш труо и шупаљ у вери, ући ће у тебе и настаниће се.

б) И ти, разумни човече, када сагрешиш много, узиђи на висину смерности и обруши се низ камен, што је вера, и разбиј нос свој, приношење греха, умиј себе у блату, то јест сузама, огреј себе на сунцу, то јест у цркви, стави своју одећу изнад греха. И затим ћеш се подмладити, као што говори пророк: Обновиће се младост твоја.

в) На такав, дакле, начин и ти, о човече, који имаш одећу старог човека и очи срца твог премрежују се, заишти засијало сунце од праведног Господа нашег Исуса Христа, коме пророци нарекоше име Исток. И он ће отворити очи срца твог. 
15.Прочитај део приче из поучног списа Физиолог (Слово о јелену и змији). Реченице у причи су испреметане. Поред сваке реченице упиши бројеве од 1 до 5 тако да добијеш логичан редослед догађаја.

Ако, пак, побегне змија од јелена у раселине земље, јелен иде по земљи.

Тако и Господ уби великог јелена са небеских вода, који имаше Бога као реч, премудрост у врлинама.

Физиолог учи да је јелен велики непријатељ змије.

1 Давид рече: Као што јелен жедни на изворима воденим, тако жуди душа наша ка теби, Боже.

Када је нањуши, убија је исецкавши је.

УПУТСТВО ЗА ПРЕГЛЕДАЬЕ И ОЦЕЊИВАЬЕ

\begin{tabular}{|c|c|c|}
\hline $\begin{array}{l}\text { Број } \\
\text { задатка }\end{array}$ & Решење & Бодовање \\
\hline 1. & в) Настанак првог словенског писма & $\begin{array}{l}\text { Тачан одговор - } \\
1 \text { бод }\end{array}$ \\
\hline 2. & $\begin{array}{l}\text { д) Полемички тон упућен је онима који оспоравају } \\
\text { употребу словенског писма. }\end{array}$ & $\begin{array}{l}\text { Тачан одговор - } \\
1 \text { бод }\end{array}$ \\
\hline 3. & $\begin{array}{l}\text { А) Јер има још живих који су их видели. } \\
\text { Б) У време писања расправе има још живих који су видели } \\
\text { Ћирила и Методија, што значи да је текст настао } \\
\text { непосредно после њихове смрти (за време трајања једног } \\
\text { људског века). }\end{array}$ & $\begin{array}{l}\text { Тачна два } \\
\text { одговора - } \\
1 \text { бод } \\
\text { Тачан један } \\
\text { одговор - 0,5 } \\
\text { бодова }\end{array}$ \\
\hline 4. & кукавни, безумницима & $\begin{array}{l}\text { Тачна два } \\
\text { одговора и } \\
\text { ниједна нетачно } \\
\text { подвучена реч - } \\
1 \text { бод }\end{array}$ \\
\hline 5. & $\begin{array}{l}\text { Лепитељ није усвојио поуке које му је славуј пренео. } \\
\text { Прву поуку лепитељ није усвојио јер покушава да ухвати } \\
\text { славуја иако не може да прати његово кретање - да лети. }\end{array}$ & $\begin{array}{l}\text { Тачан одговор - } \\
1 \text { бод }\end{array}$ \\
\hline
\end{tabular}




\begin{tabular}{|c|c|c|}
\hline & $\begin{array}{l}\text { Другу поуку лепитељ није усвојио зато што се каје јер је } \\
\text { пустио славуја. } \\
\text { Трећу поуку лепитељ није усвојио јер је поверовао славују } \\
\text { да се у његовој утроби налази бисер већи него нојево јаје. } \\
\text { То је невероватно јер је славуј мањи од нојевог јајета. }\end{array}$ & \\
\hline 6. & $\begin{array}{l}\text { б) Истиче се грешност и ништавност човека. } \\
\text { г) Парафразирају се мисли из Библије. } \\
\text { д) Истиче се човекова окренутост ка Богу у најтежим } \\
\text { тренуцима. }\end{array}$ & $\begin{array}{l}\text { Тачна три } \\
\text { одговора - } \\
1 \text { бод } \\
\text { Тачна два } \\
\text { одговора и } \\
\text { ниједан нетачан } \\
\text { - } \\
0,5 \text { бодова }\end{array}$ \\
\hline 7. & $\begin{array}{l}\text { А) Прихватљив је сваки одговор који је заснован на тексту } \\
\text { и у коме се уочавају следећи елементи Савиног односа } \\
\text { према себи: недостојност, грешност, услужност, понизност } \\
\text { пред Богом и другим људима. Овакав однос према себи } \\
\text { може се довести у везу са поетиком средњовековне } \\
\text { књижевности, али и не мора. } \\
\text { Б) Прихватљив је сваки одговор који је заснован на тексту } \\
\text { и у коме се уочава веза између приповедања у трећем лицу } \\
\text { и неког од следећих елемената: } \\
- \text { објективно приповедање / неутрално сведочење о } \\
\text { догађајима; } \\
- \text { симболичка дистанца између монашког и световног } \\
\text { живота; } \\
- \text { жеља за неистицањем и непридавањем важности } \\
\text { сопственој личности; } \\
\text {-другачији однос према ауторству него у савременог } \\
\text { књижевности. }\end{array}$ & $\begin{array}{l}\text { Тачна два } \\
\text { одговора - } \\
1 \text { бод } \\
\text { Тачан један } \\
\text { одговор }-0,5 \\
\text { бодова }\end{array}$ \\
\hline 8. & (Косовски / мраморни) стуб & $\begin{array}{l}\text { Тачан одговор - } \\
1 \text { бод }\end{array}$ \\
\hline 9. & Пролазницима / људима који дођу на Косово & $\begin{array}{l}\text { Тачан одговор - } \\
1 \text { бод }\end{array}$ \\
\hline 10. & $\begin{array}{l}\text { У мраморном / мермерном / каменом облику; } \\
\text { на мрамору / мермеру / камену }\end{array}$ & $\begin{array}{l}\text { Тачан одговор - } \\
1 \text { бод }\end{array}$ \\
\hline 11. & $\begin{array}{l}\text { Прихватљив је сваки одговор који садржи најмање три } \\
\text { тематске целине засноване на тексту. Тематске целине } \\
\text { ученици могу формулисати на различите начине. } \\
\text { На пример: обраћање путнику; указивање на значај } \\
\text { натписа; указивање на узрок постављања стуба; скретање }\end{array}$ & $\begin{array}{l}\text { Тачан одговор - } \\
1 \text { бод }\end{array}$ \\
\hline
\end{tabular}




\begin{tabular}{|c|c|c|}
\hline & $\begin{array}{l}\text { пажње на истинитост натписа; величање кнеза Лазара; } \\
\text { величање српске војске; опис битке; опис погибије кнеза } \\
\text { Лазара. }\end{array}$ & \\
\hline 12. & $\begin{array}{l}\text { Јер истину ти говорим } \\
\text { ништа мање од живога } \\
\text { да ћу вам изнети у суштини све што се збило. }\end{array}$ & $\begin{array}{l}\text { Тачан одговор - } \\
1 \text { бод }\end{array}$ \\
\hline 13. & $\begin{array}{l}\text { a) Велича се храброст и племенитост кнеза Лазара, који } \\
\text { представља врхунац људске духовности. } \\
\text { г) Указује се на два аспекта борбе, први који подразумева } \\
\text { овоземаљску победу и други који доноси небеску славу. }\end{array}$ & $\begin{array}{l}\text { Тачна два } \\
\text { одговора }- \\
1 \text { бод } \\
\text { Тачан један } \\
\text { одговор } \\
\text { ниједан нетачан } \\
- \\
0,5 \text { бодова }\end{array}$ \\
\hline 14. & $\begin{array}{l}\text { б) И ти, разумни човече, када сагрешиш много, узиђи на } \\
\text { висину смерности и обруши се низ камен, што је вера, и } \\
\text { разбиј нос свој, приношење греха, умиј себе у блату, то } \\
\text { јест сузама, огреј себе на сунцу, то јест у цркви, стави } \\
\text { своју одећу изнад греха. И затим ћеш се подмладити, као } \\
\text { што говори пророк: Обновиће се младост твоја. }\end{array}$ & $\begin{array}{l}\text { Тачан одговор - } \\
1 \text { бод }\end{array}$ \\
\hline 15. & 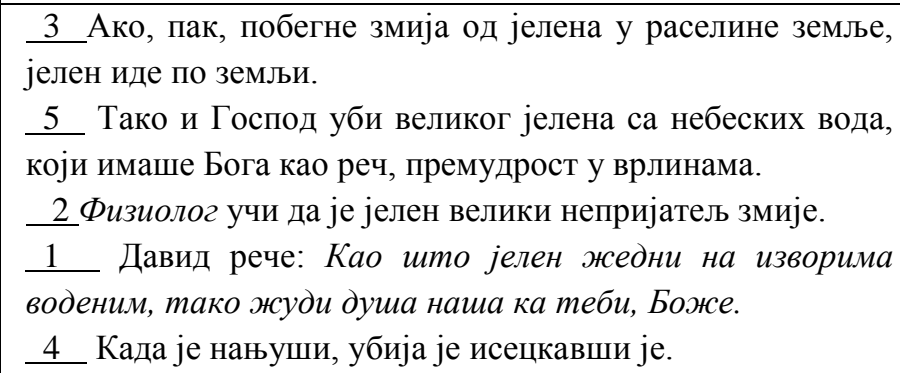 & $\begin{array}{l}\text { Тачан одговор - } \\
1 \text { бод }\end{array}$ \\
\hline
\end{tabular}

\section{СПЕЦИФИКАЦИЈА ТЕСТА}

\begin{tabular}{|l|l|l|l|l|}
\hline $\begin{array}{l}\text { Број } \\
\text { задатка }\end{array}$ & Тип задатка & Ниво & \multicolumn{2}{|l|}{ Образовни стандард / дескриптор } \\
\hline 1. & $\begin{array}{l}\text { Затворен } \\
\text { тип, } \\
\text { вишеструки } \\
\text { избор }\end{array}$ & Основни & 2.СЈК.1.3.2. & Разликује битно од небитног. \\
\hline 2. & $\begin{array}{l}\text { Затворен } \\
\text { тип, } \\
\text { вишеструки } \\
\text { избор }\end{array}$ & Основни & 2.СЈК.1.3.6. & $\begin{array}{l}\text { Разуме књижевни и неуметнички } \\
\text { текст средње сложености. }\end{array}$ \\
\hline
\end{tabular}




\begin{tabular}{|c|c|c|c|c|}
\hline 3. & $\begin{array}{l}\text { Отворен тип, } \\
\text { продужени } \\
\text { одговор }\end{array}$ & Средњи & 2.CJK.2.3.4. & $\begin{array}{l}\text { Разуме сложенији књижевни и } \\
\text { неуметнички текст, проналази } \\
\text { експлицитне и имплицитне } \\
\text { информације. }\end{array}$ \\
\hline 4. & $\begin{array}{l}\text { Затворен } \\
\text { тип, кратак } \\
\text { одговор }\end{array}$ & Основни & 2.СЈК.1.3.7. & $\begin{array}{l}\text { Критички промишља књижевни и } \\
\text { неуметнички текст средње } \\
\text { сложености; разликује } \\
\text { објективну/веродостојну чињеницу од } \\
\text { ауторове интерпретације; процењује } \\
\text { да ли је аутор текста неутралан или } \\
\text { ангажован, односно пристрасан. }\end{array}$ \\
\hline 5. & $\begin{array}{l}\text { Отворен тип, } \\
\text { есејски } \\
\text { одговор }\end{array}$ & Напредни & 2.СЈК.3.3.5. & $\begin{array}{l}\text { Продубљено критички промишља } \\
\text { сложенији текст. }\end{array}$ \\
\hline 6. & $\begin{array}{l}\text { Затворен } \\
\text { тип, } \\
\text { вишеструки } \\
\text { избор }\end{array}$ & Напредни & 2.СЈK.3.3.4. & $\begin{array}{l}\text { Организује, класификује, уопштава и } \\
\text { на сличан начин обрађује } \\
\text { информације из књижевних и } \\
\text { неуметничких текстова на основу } \\
\text { задатог и/или самостално } \\
\text { постављеног критеријума. }\end{array}$ \\
\hline 7. & $\begin{array}{l}\text { Отворен тип, } \\
\text { есејски } \\
\text { одговор }\end{array}$ & Напредни & 2.СЈК.3.3.5. & $\begin{array}{l}\text { Продубљено критички промишља } \\
\text { сложенији текст. }\end{array}$ \\
\hline 8. & $\begin{array}{l}\text { Отворен тип, } \\
\text { кратак } \\
\text { одговор }\end{array}$ & Средњи & 2.СЈК.2.3.4. & $\begin{array}{l}\text { Разуме сложенији књижевни и } \\
\text { неуметнички текст, издваја } \\
\text { информације према задатом } \\
\text { критеријуму. }\end{array}$ \\
\hline 9. & $\begin{array}{l}\text { Отворен тип, } \\
\text { кратак } \\
\text { одговор }\end{array}$ & Средњи & 2.СЈК.2.3.4. & $\begin{array}{l}\text { Разуме сложенији књижевни и } \\
\text { неуметнички текст, издваја } \\
\text { информације према задатом } \\
\text { критеријуму. }\end{array}$ \\
\hline 10. & $\begin{array}{l}\text { Отворен тип, } \\
\text { кратак } \\
\text { одговор }\end{array}$ & Основни & 2.СЈК.1.3.6. & $\begin{array}{l}\text { Проналази експлицитне и имплицитне } \\
\text { информације у тексту средње } \\
\text { сложености. }\end{array}$ \\
\hline 11. & $\begin{array}{l}\text { Отворен тип, } \\
\text { продужени } \\
\text { одговор }\end{array}$ & Средњи & 2.СЈK.2.3.2. & $\begin{array}{l}\text { Резимира сложенији књижевни и } \\
\text { неуметнички текст. }\end{array}$ \\
\hline 12. & $\begin{array}{l}\text { Затворен } \\
\text { тип, } \\
\text { продужени } \\
\text { одговор }\end{array}$ & Напредни & 2.СЈК.3.3.6. & $\begin{array}{l}\text { Процењује стилске поступке у } \\
\text { књижевном и неуметничком тексту. }\end{array}$ \\
\hline
\end{tabular}




\begin{tabular}{|l|l|l|l|l|}
\hline 13. & $\begin{array}{l}\text { Затворен } \\
\text { тип, } \\
\text { вишеструки } \\
\text { избор }\end{array}$ & Основни & 2.СЈК.1.3.6. & $\begin{array}{l}\text { Разуме књижевни и неуметнички } \\
\text { текст средње сложености. Издваја } \\
\text { главне идеје текста; прати развој } \\
\text { одређене идеје у тексту. }\end{array}$ \\
\hline 14. & $\begin{array}{l}\text { Затворен } \\
\text { тип, } \\
\text { вишеструки } \\
\text { избор }\end{array}$ & Средњи & 2.СЈК.2.3.4. & $\begin{array}{l}\text { Пореди информације и идеје из двају } \\
\text { или више текстова да би разумео } \\
\text { одговарајући значењски или стилски } \\
\text { аспект према задатом критеријуму. }\end{array}$ \\
\hline 15. & $\begin{array}{l}\text { Затворен } \\
\text { одп, кратак }\end{array}$ & Напредни & 2.СЈК.3.3.4. & $\begin{array}{l}\text { Организује, класификује, уопштава и } \\
\text { на сличан начин обрађује } \\
\text { информације из књижевних и } \\
\text { неуметничких текстова на основу } \\
\text { задатог и/или самостално } \\
\text { постављеног критеријума. }\end{array}$ \\
\hline
\end{tabular}

